\title{
Ethnopharmacological survey and antibacterial activity of medicinal plant extracts used against bacterial enteritis in rabbits
}

\author{
Mireille Tuedom Chouegouong ${ }^{1,2} \cdot$ Michele Stella Majoumouo $^{1}$. Elisabeth Zeuko'o Menkem ${ }^{1,3}$. \\ Lorette Victorine Yimgang ${ }^{1} \cdot$ Rufin Marie Kouipou Toghueo ${ }^{1}$ (D . Kingsley Agbor Etchu ${ }^{2} \cdot$ Fabrice Fekam Boyom ${ }^{1}$
}

Received: 28 June 2021 / Accepted: 5 September 2021 / Published online: 19 October 2021

(c) The Author(s) 2021

\begin{abstract}
Bacterial enteritis is one of the diseases negatively affecting the rabbit farming industry. Communities across the globe are using medicinal plants as an alternative treatment against many diseases in rabbits. This study aimed at identifying medicinal plants used by local farmers in Cameroon and evaluate their antibacterial activity alone and in combination with oxytetracycline against some bacterial causative agents of diarrhoea in rabbits. The ethnopharmacological survey was performed in Cameroon's Western and Central regions, where breeders were interviewed about their knowledge on the medicinal plants and plant parts often used to cure rabbit diseases, the methods of preparation and the route of administration. Plants were collected, and extracts were prepared by decoction, infusion and maceration using distilled water. The antibacterial activity of extracts and combinations was evaluated against enteropathogenic Escherichia coli, Salmonella enterica and Clostridium perfringens (WAL-14572 HM-310) using the microdilution and checkerboard methods. From the survey, fifteen medicinal plants belonging to nine families, with Asteraceae being the most represented, were identified as currently used to treat diarrhoea in rabbits. Bidens pilosa and Psidium guajava were the most mentioned medicinal plant species with 24 and 17 citations, respectively. Leaves were the most commonly used plant parts, and maceration in water was the primary preparation method of remedies administered orally. Out of the forty-five extracts prepared, only six from Tithonia diversifolia $\left(T d \mathrm{l}^{\mathrm{M}}, T d \mathrm{l}^{\mathrm{I}}, T d \mathrm{l}^{\mathrm{D}}\right)$ and Psidium guajava $\left(P g \mathrm{I}^{\mathrm{M}}, P g \mathrm{l}^{\mathrm{I}}, P g \mathrm{I}^{\mathrm{D}}\right)$ exhibited potency with MIC values ranging from 1.25 to $5 \mathrm{mg} / \mathrm{mL}$. The combination of infusion extract from leaves of Tithonia diversifolia $\left(T d \mathrm{l}^{\mathrm{I}}\right)$ and decoction extract from Psidium guajava $\left(\right.$ Pgl $\left.^{\mathrm{D}}\right)$ exhibited synergistic interaction $(\mathrm{FICI}=0.312 ; 0.281 ; 0.265$ ), while oxytetracycline in combination with decoction extract from leaves of Psidium guajava $\left(\mathrm{Pg}^{\mathrm{D}}\right)$ exhibited a synergistic interaction $(\mathrm{FICI}=0.5)$. The phytochemical screening of the six extracts revealed polyphenols, glycosides, saponins, terpenoids, anthraquinones, tannins and flavonoids. The antibacterial activity of extracts from medicinal plants P. guajava and T. diversifolia demonstrated in the present study supports the use of these plants by farmers of the targeted localities to treat diarrhoea in rabbits.
\end{abstract}

Keywords Rabbits $\cdot$ Ethnopharmacological survey $\cdot$ Psidium guajava Tithonia diversifolia $\cdot$ Antibacterial $\cdot$ Combination

Rufin Marie Kouipou Toghueo

toghueo.rufin@yahoo.fr

$\triangle$ Fabrice Fekam Boyom fabrice.boyom@fulbrightmail.org

1 Antimicrobial and Biocontrol Agents Unit, Laboratory for Phytobiochemistry and Medicinal Plants Studies, Department of Biochemistry, Faculty of Science, University of Yaoundé I, P.O. Box 812, Yaoundé, Cameroon

2 Institute of Agricultural Research for Development (IRAD), P.O. Box 2067, Yaoundé, Cameroon

3 Department of Biomedical Sciences, Faculty of Health Sciences, University of Buea, PO Box 63, Buea, Cameroon

$\begin{array}{ll}\text { Abbreviations } \\ \text { BEI } & \text { Biodefense and emerging infections } \\ \text { CP } & \text { Clostridium perfringens } \\ \text { CLSI } & \text { Clinical and laboratory standard institute } \\ \text { MIC } & \text { Minimal inhibitory concentration } \\ \text { CFU } & \text { Colony-forming units } \\ \text { DMSO } & \text { Dimethylsulfoxide } \\ \text { EPEC } & \text { Enteropathogenic Escherichia coli } \\ \text { FAOSTAT } & \text { Food and agriculture organization corporate } \\ & \text { statistical } \\ \text { FIC } & \text { Fractional inhibitory concentration } \\ \text { FICI } & \text { Fractional inhibitory concentration index } \\ \text { HNC } & \text { Herbier national du Cameroun }\end{array}$

Abbreviations 


$\begin{array}{ll}\text { IRAD } & \begin{array}{l}\text { Institute of agricultural research for } \\ \text { development }\end{array} \\ \text { MHB } & \text { Mueller Hinton broth } \\ \text { Oxy } & \text { Oxytetracycline } \\ \text { Pgl }^{\mathrm{M}} & \text { Macerated leaf of } \text { P. guajava } \\ \text { Pgl }^{\mathrm{I}} & \text { Infused leaf of } P \text {. guajava } \\ P_{\text {g }}{ }^{\mathrm{D}} & \text { Decocted leaf of } \text { P. guajava } \\ \mathrm{SE} & \text { Salmonella enterica } \\ T d \mathrm{l}^{\mathrm{M}} & \text { Macerated leaf of Tithonia diversifolia } \\ T d \mathrm{l}^{\mathrm{I}} & \text { Infused leaf of } T \text {. diversifolia } \\ T d \mathrm{l}^{\mathrm{D}} & \text { Decocted leaf of } \text { T. diversifolia }\end{array}$

\section{Introduction}

Rabbit (Oryctolagus cuniculi) farming is gaining momentum in the world. Indeed, between 2008 and 2018, the worldwide production of rabbit meat increased by $9.8 \%$ (FAOSTAT 2020). China is currently the world's leading producer (700,000 t/year) while Italy $(230,000 \mathrm{t} /$ year), Spain $(74,161$ t/year) and France (51,400 t/year) are the leading producers in Europe (FAOSTAT 2020). In Cameroon, the Ministry of Livestock, Fisheries and Animal Industries reported that rabbit meat is the fourth largest meat product in the country, ranked just behind beef, pork and poultry meats. This trend is also observed in many other African countries (Powell 2021).

Rabbit farming appears as an attractive proposition for the supply of high-quality meat globally due to attributes such as its high fertility, prolificacy, rapid growth and low cost of production (El-Ashram et al. 2020). Moreover, rabbit meat is a great functional food, offering excellent nutritive and dietetic properties. Rabbit meat is rich in proteins and contains high essential amino-acid levels. The consumption of $100 \mathrm{~g}$ of rabbit meat provides around $1.2-1.3 \mathrm{~g}$ of minerals while providing about $8 \%$ of the daily requirement of vitamin B2, $12 \%$ of vitamin B5, $21 \%$ of vitamin B6, and $77 \%$ of vitamin B3. Rabbit meat also contains low lipids while providing moderately high energy values mainly through proteins, accounting for $80 \%$ of the energy value (Hernández and Zotte 2010; Dalle Zotte and Szendrő 2011).

Unfortunately, rabbits are prone to gastrointestinal tract diseases, among which bacterial enteritis. Enteritis commonly observed in rabbits can cause high death rates in commercial farming leading to a significant loss in productivity and profit (Gómez 2006; DeCubellis and Graham 2013). For instance, rabbit's mortality due to enteritis has been reported to cause between $4.03 \%$ and $17.12 \%$ of economic losses each year between 2006 and 2010 in grower's farm in Tamil Nadu, India (Pasupathi et al. 2014) and 3.4\% death was recorded in a commercial farm in Spain between 2000 and 2005 (Rosell and de la Fuente 2009). The most important pathogens responsible for diarrhoea in rabbits include enteropathogenic strains of Escherichia coli, Salmonella sp., and Clostridium perfringens (El-Ashram et al., 2020; Kupczyński et al., 2011; Oglesbee and Lord, 2020), affecting the weaning, a crucial period in the productive cycle of rabbits (McNitt et al. 2013). For the management of diarrhoea in rabbits, antibiotics such as tetracycline or oxytetracycline and derivatives are intensively used. Consequently, drug residues in animal meats is causing harmful effects on health and increasing the development of microbial resistance in human (Kylie et al. 2017). Therefore, the interest in alternate therapeutic/preventive agents, such as herbal preparations, has increased over the years.

Indeed, medicinal plants' preventive and therapeutic applications in the management of animal diseases are known for many years. Small-scale farmers use single or the combination of several plants with antimicrobial properties to control diseases in rabbits because of the accessibility, availability and effectiveness (Meineri et al. 2010; Kupczyński et al. 2019; Dzoyem et al. 2020). Given the reports on the beneficial effects of plants extracts as a dietary additive on production parameters, quality of animal origin products, and animal health, investigating such medicinal plants could provide an alternative therapeutic avenue for the management of bacterial enteritis in small-scale and commercial farms (Szabóová et al. 2012). Therefore, this study was designed to conduct an ethnopharmacological survey in five localities of Cameroon to identify medicinal plants used by local farmers to treat diarrhoea in rabbits. The antibacterial activity of extracts from the selected plants and some combinations against enteropathogenic Escherichia coli, Salmonella enterica and Clostridium perfringens was also investigated.

\section{Materials and methods}

\section{Ethnopharmacology survey}

\section{Study area}

The study was carried out from January 5 to March 15 , 2019, in two regions of Cameroon. The Western region included two divisions namely Koung-Khi (Bandjoun) and Mifi (Bafoussam II subdivision), while the Centre region included the Mfoundi (Yaoundé I, Yaoundé VI, and Yaoundé VII subdivision), Mefou-et-Afamba (Awaé), and Lékié (Monatélé). The whole study area is located between $5^{\circ} 30^{\prime}$ $\mathrm{N}$ and $10^{\circ} 30^{\prime} \mathrm{E}, 3^{\circ} 51^{\prime}$ to $3^{\circ} 53^{\prime} \mathrm{N}$ and $11^{\circ} 25^{\prime}$ to $11^{\circ} 27^{\prime} \mathrm{E}$ (Fig. 1).

With a population of more than 1720047 and a density of 123.8 inhabitants per $\mathrm{Km}^{2}$, the West region covers an area of $14000 \mathrm{~km}^{2}$, making it one of the most densely populated regions in Cameroon. The relief of the West 


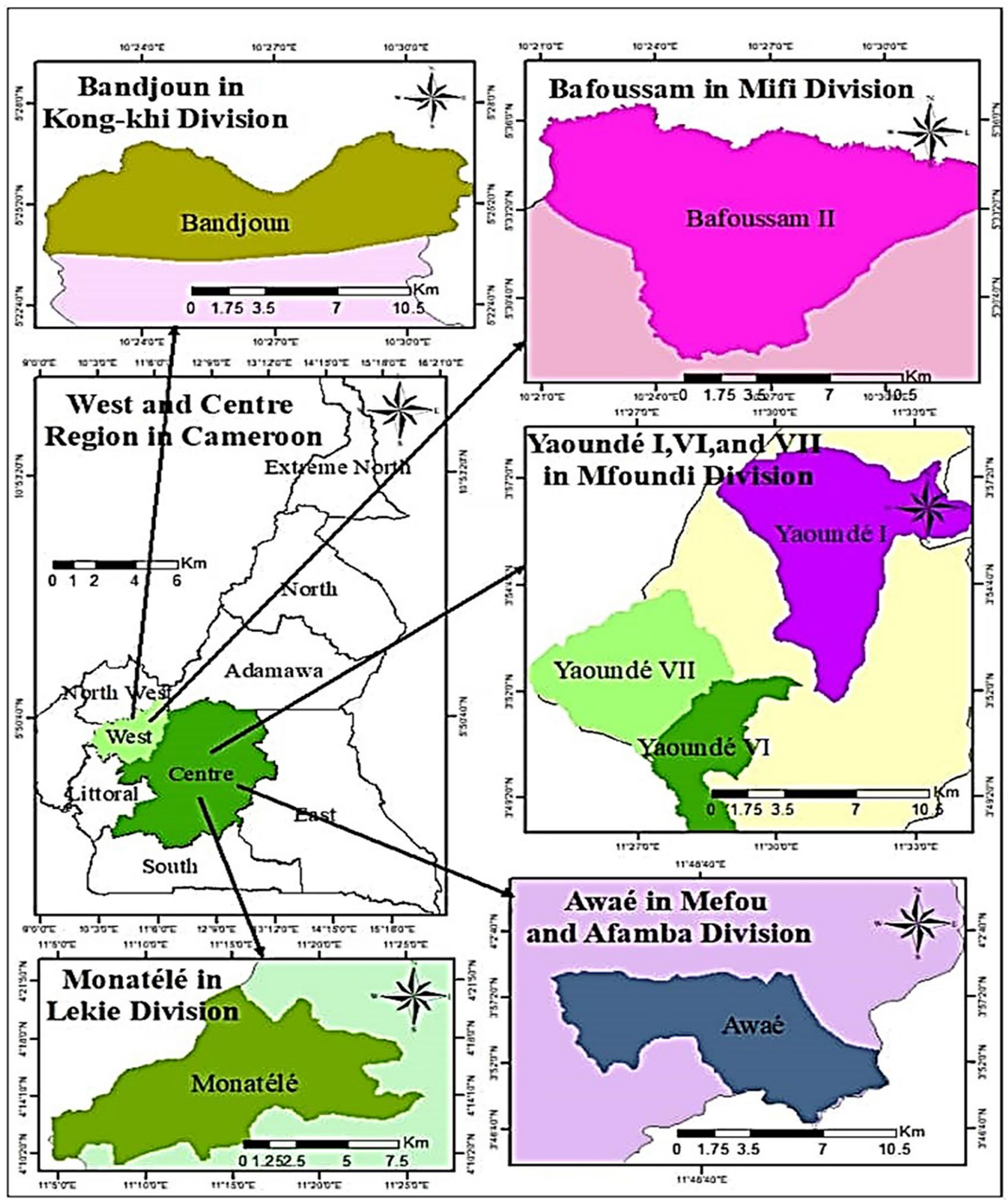

Fig. 1 Location of the study sites 
region is mountainous (plateaus and plains), with the tropical Sudanese's climate composed of two main seasons, including the dry (December-March) and the rainy season (March-November). Through the year, the temperatures vary between 15 and $30{ }^{\circ} \mathrm{C}$ on average, with a solid daily variation (Tchetgna 2012). On the other hand, the centre region with more than 1.299.369 inhabitants extends over $69.0000 \mathrm{~km}^{2}$. With the sub-equatorial climate and four seasons including a large dry (mid-November to late March), a short rainy (April to mid-June), a short dry (mid-June to mid-August) and a long rainy (mid-August to mid-November) (Nematchoua et al. 2014), it is an agroecological region of humid forest with a bimodal rainfall varying between 1500 and $2500 \mathrm{~mm} /$ year, a relative humidity of $70-90 \%$ and the temperature averaging $25{ }^{\circ} \mathrm{C}$ through the year (Moustapha et al. 2021). These localities were selected preliminarily based on small-scale rabbit's farmers using medicinal plants to treat diarrhoea and related symptoms. Subsequently, the identification of plants with associated recipes was achieved through face-to-face interaction with farmers.

\section{Data collection}

The authorisation for the survey was obtained from the regional delegation of the ministry of livestock, fisheries and animal industries from West and Centre regions of Cameroon (supplementary materials 3 ). Before the start of the ethnobotanical data collection, we explained the goal of our study to informants. We requested their consent for capitalising their knowledge in a published document to avoid knowledge erosion through time. Contacted via the office of their respective regional delegations of livestock management, the forty-seven rabbit farmers, both men and women (20-50 plus years) from both regions who give consent to participate in the study, were interviewed using the snowball sampling technique according to a semi-structured questionnaire (supplementary material 4) which was previously prepared in the French language (Martin 1995). Using both an individual and focus group discussion, breeders were surveyed for their general profile, including their breeding experience, the mortality rate often recorded and the principal causes, the primary diseases affecting rabbits and the treatment and prevention methods employed. Moreover, the information on each medicinal plant, including the vernacular name, medical use, plant parts, mode of preparation, route of administration, the solvent used, the dosage, the length of treatment and the degree of satisfaction relative to each treatment was also surveyed. Each informant was interviewed at least twice to verify the relevance and confirm the information collected.
With the oral consent and aid from each local breeder, fresh plant specimens were collected, dried and stored in the laboratory of the Department of Biochemistry of the Faculty of Science of the University of Yaoundé 1 . They were later identified at the National Herbarium of Cameroon, Yaoundé, where their full scientific names and voucher number were obtained. Further literature investigations were also conducted relatively to their therapeutic and/or pharmacological effects and their phytochemical composition if any.

\section{Preparation of crude extracts}

The fresh plant materials were washed separately with fresh tap water to remove dirt and other contaminants, shade-dried for three weeks until constant weight was recorded, and ground to fine powders. $100 \mathrm{~g}$ of powder was transferred in different Erlenmeyer flasks and macerated under shaking for $72 \mathrm{~h}$ in $500 \mathrm{~mL}$ of cold distilled water to prepare macerated extracts, heated for 5-10 min to prepare infusion extracts and boiling in distilled water for $30 \mathrm{~min}$ to prepare decocted extracts. The aqueous, infusion and decoction filtrates were sieved using hydrophilic cotton and filtered using Whatman filter paper $\mathrm{N}^{\mathrm{o}} 1$. The organic filtrates were dried at $25{ }^{\circ} \mathrm{C}$ under constant ventilation to obtain crude extracts. The extracts were preserved in sterile bottles and conserved at $4{ }^{\circ} \mathrm{C}$ for further experiments.

\section{In vitro antimicrobial assay}

\section{Microbial species and culture media}

Three bacteria, including Clostridium perfringens WAL14572 HM-310, obtained from BEI Resources (BEI Resources, Rockville, MD 20, 852), Enteropathogenic Escherichia coli (EPEC) and Salmonella enterica obtained from the Institute of Agricultural Research for Development (IRAD) of Wakwa, Ngaoundéré, Cameroon were used. The microorganisms were maintained on an agar slope at $4{ }^{\circ} \mathrm{C}$ and sub-cultured for $24 \mathrm{~h}$ before each experiment.

\section{Preliminary screening and MIC determination}

The forty-five extracts were screened at $5 \mathrm{mg} / \mathrm{mL}$ for their ability to inhibit bacteria species according to the following procedure: ninety-two microliters $(92 \mu \mathrm{L})$ of Muller Hinton broth (MHB) were aseptically introduced into the wells of a $96-$-well micro-plate. Eight microliters $(8 \mu \mathrm{L})$ of each extract, initially prepared at $125 \mathrm{mg} / \mathrm{mL}$, were added in wells followed by $100 \mu \mathrm{L}$ of standardised bacterial suspension $\left(10^{6} \mathrm{CFU} / \mathrm{mL}\right)$ to obtain final volumes of $200 \mu \mathrm{L}$. The tests were performed simultaneously for negative control (MHB + pathogens) and sterility control (MHB alone). Oxytetracycline $20 \%$ was used as the positive control and tested 
at $0.5 \mathrm{mg} / \mathrm{mL}$. The plates were incubated at $37{ }^{\circ} \mathrm{C}$ for $24 \mathrm{~h}$. The test was performed in duplicate and repeated thrice and the selected active extracts were further submitted to the dose-response study for MIC determination.

The minimum inhibitory concentration (MIC) of selected extracts was determined according to the M07-A9 Clinical Laboratory Standards Institute (CLSI) microdilution method using 96 -wells microtitre plates. Briefly, $4 \mu \mathrm{L}$ of extracts and reference drug (Oxytetracycline 20\%) from stock solutions were introduced in the well, followed by the addition of 96 $\mu \mathrm{L}$ of bacteria inoculum standardised at $10^{6} \mathrm{CFU} / \mathrm{mL}$. A blank column was included for sterility control, while bacterial strains in culture medium without any inhibiting substance were negative control. The concentrations of extracts ranged from 0.625 to $5 \mathrm{mg} / \mathrm{mL}$, and that of Oxytetracycline $20 \%$ ranged from $0.1 \times 10^{-6}$ to $0.50 \mathrm{mg} / \mathrm{mL}$. After $24 \mathrm{~h}$ of incubation at $37^{\circ} \mathrm{C}$, the turbidity was observed as an indication of growth. MIC was defined as the lowest concentration inhibiting the visible growth of microorganisms. All tests were performed in duplicate and repeated thrice.

\section{Antibacterial activity of combined extracts against Enteropathogenic Escherichia coli}

Three extracts from the two plants were combined to give three interspecies combinations, with no combination between extracts from the same plant. Moreover, the combination between extracts and Oxytetracycline 20\% were also evaluated. The checkerboard microdilution assay was used to determine fractional inhibitory concentration indexes (FICIs) of combination of extracts against Enteropathogenic E. coli. The checkerboard broth microdilution method based on CLSI recommendations consisted of diluting extracts/compound in the two directions of a 96-wells microplate with the mixed concentrations in wells ranging from $1 / 64 \times$ MIC to $2 \times$ MIC. The bacterial inoculum was adjusted to give $10^{6} \mathrm{CFU} / \mathrm{mL}$ an ultimate concentration in a final volume of $100 \mu \mathrm{L}$. Therefore, the plates were incubated at $37^{\circ} \mathrm{C}$ for $24 \mathrm{~h}$, and each test was performed in duplicate and repeated thrice. The changes in the Fractional Inhibitory Concentration Indexes (FICIs) were calculated using the following formula, and the type of interaction was determined according to previously described criteria.

$\mathrm{FICI}(\mathrm{X} 1 / \mathrm{X} 2)=\mathrm{MICX} 1$ in combination/MICX1 alone + MICX2 in combination/MICX2 alone.

Based on these criteria, a combination was considered to be synergistic when the FICI was $\leq 0.5$, additive when it was $>0.5$ to $\leq 1$, indifferent when it was $>1.0$ to $\leq 4.0$. Antagonism was obtained with FICI $>4.0$ (van Vuuren and Viljoen 2011).

\section{Phytochemical screening}

The presence of major phytochemical classes of compounds such as anthraquinones, flavonoids, glycosides, phenols, saponins, steroids, tannins, and terpenoids was qualitatively evaluated in the plant extracts using standard preliminary phytochemical analysis as previously described (Harborne 1998).

Test for anthraquinones: About $1.0 \mathrm{mg}$ of each extract was reacted with $2.0 \mathrm{~mL}$ benzene, shaken properly, and filtered through Whatman's no. 1 filter paper. Then, the filtrates were allowed to react with $2.5 \mathrm{~mL}$ of $10 \%$ ammonia solution and shaken properly. The presence of pink, red, or violet colour in ammonia solution in the lower phase indicates a positive result.

Test for glycosides: About $1.25 \mathrm{mg}$ of each extract was allowed to react with $0.5 \mathrm{~mL}$ chloroform and mixed carefully. About $0.5 \mathrm{~mL}$ of concentrated sulfuric acid was then carefully added to form a lower layer. The reddish-brown colour at the interface indicates the presence of a steroidal ring, the glycone portion of glycosides.

Test for flavonoids: About $7.5 \mathrm{mg}$ of each dry extract was dissolved in $0.5 \mathrm{~mL}$ of ethanol, concentrated $\mathrm{HCl}$, and magnesium turnings. A yellowish coloration indicates the presence of flavonoids.

Test for phenols: The crude extract of the plant material was treated with 3 to 4 drops of ferric chloride solution, or dissolving $5.0 \mathrm{mg}$ of dry extract in $0.5 \mathrm{~mL}$ of $1 \%$ ferric chloride solution. The formation of bluish-black colour indicates the presence of phenolic compounds.

Test for saponins: About $2.5 \mathrm{mg}$ of the plant extract was dissolved with $5.0 \mathrm{~mL}$ water and shaken properly in a test tube. Samples showing froth were warmed. Persistent foam formation indicates the presence of saponin.

Tests for steroids: In a $10 \mathrm{~mL}$ glass tube, a mixture of $1.0 \mathrm{~mL}$ of extract, $1.0 \mathrm{~mL}$ of chloroform and $1.0 \mathrm{~mL}$ of acetic anhydride was prepared. Then 2 drops of concentrated $\mathrm{H}_{2} \mathrm{SO}_{4}$ was added from the side of test tube. The development of red, then blue and finally green colour was indicative of the presence of steroids.

Test for tannins: About $2.5 \mathrm{mg}$ of each plant extract was boiled in $5.0 \mathrm{~mL}$ of water in a test tube and then filtered through Whatman's No. 1 filter paper. Two to three drops of $0.1 \%$ ferric chloride added and read for brownish green or a blue-black precipitate indicating a positive result.

Test for terpenoids: About $0.5 \mathrm{~mL}$ of the chloroform extract of the dried extracts was evaporated to dryness on a water bath and heated with $3.0 \mathrm{~mL}$ of concentrated sulfuric acid for $10 \mathrm{~min}$ on a water bath. The gray colour indicates the presence of terpenoids. 


\section{Statistical analyses}

Microsoft Excel 2016 software for Windows was used to calculate the number of recurrences and percentage of the plant use, knowledge on the use of medicinal plants. The sex and age of participant compared using $\mathrm{khi}^{2}$ and fishers tests. The results were presented as the Mean \pm SD of the replicated values for each independent experiment.

\section{Results}

\section{Repartition of informants}

During the ethnobotanical investigation inclusion of informants in this study depended on their agreement to participate. Those who refused claimed that scientists were trying to steal their knowledge and therefore could not cooperate; secondly, others rejected the offer claiming the allowance unsubstantial. At final, 47 breeders, including 28 from the Western and 19 from the Centre, agreed to work with us by providing information on their breeding experience and the medicinal plants they are using to treat diarrhoea in rabbits. Over $85 \%$ of informants were male, ranging from 20 to 49 years old. Most of them $(68.09 \%)$ used the medicinal plants to treat diarrhoea (Table 1).

\section{Distribution of plants species used according to locality and frequency}

The informants in the study area, to treat diarrhoea and related symptoms in rabbits reported using fifteen (15) medicinal plants species belonging to 14 genera ( 9 families). Asteraceae family, with seven plant species listed

Table 1 The distribution of respondents according to sex, age and usage of medicinal plants

\begin{tabular}{llllll}
\hline $\mathrm{N}^{0}$ & Variables & $\begin{array}{l}\text { Number of } \\
\text { individuals } \\
(\mathrm{N}=47)\end{array}$ & Percentage (\%) & $P$-value & $\mathrm{X}^{2}$ \\
\hline 1 & Sex & & & & \\
& Male & 40 & 85.11 & $<0.0001$ & N/A \\
& Female & 7 & 14.89 & & \\
2 & Age groups & & & \\
& $20-29$ & 19 & 40.43 & 0.0820 & 6.702 \\
& $30-39$ & 11 & 23.40 & & \\
& $40-49$ & 10 & 21.28 & & \\
& 50 \& plus & 7 & 14.89 & & \\
3 & Use of medicinal plants & & & \\
& Yes & 32 & 68.09 & 0.0240 & N/A \\
& No & 15 & 31.91 & & \\
\hline
\end{tabular}

N/A Not applicable was the most represented. More than $50 \%$ of the farmers reported using plants to treat diarrhoea in rabbits. Bidens pilosa and Psidium guajava, with the frequencies of citation ranging from 75 to $81.48 \%$ and $51.85-53.13 \%$, respectively were the more common plants used by farmers in both regions of Cameroon. Leaves $(86.66 \%)$ were primarily organs used to prepare remedies, mostly by maceration into water. The seeds of Carica papaya Linn and P. guajava Linn were also used for treatment by mixing with feed. For Euphorbia hirta Linn and B. pilosa Linn, the entire plant was macerated in water to prepare the oral medication. Other plants derived substances such as charcoal powder was reported to be used to treat diarrhoea via oral administration, while palm oil-kerosene was also used to treat rashes by applying topically on the rabbit skin. The Table 2 lists the recorded species, the parts used, the preparation and mode of administration in managing diarrhoea and related symptoms in rabbits in the five localities surveyed.

\section{Antibacterial screening and minimum inhibitory concentration (MIC) of extracts}

From the 15 medicinal plants collected, three extracts type from each plant, including cold water, infused, and decocted extracts, were prepared and screened for activity against three bacterial pathogens. Out of the fortyfive extracts tested, only six, including three from leaves of $T$. diversifolia $\left(T d \mathrm{l}^{\mathrm{M}}, T d \mathrm{l}^{\mathrm{I}}, T d \mathrm{l}^{\mathrm{D}}\right)$ and three from $P$. guajava $\left(P g 1^{\mathrm{M}}, P g 1^{\mathrm{I}}, P g 1^{\mathrm{D}}\right)$ were active against the tested bacteria at $5 \mathrm{mg} / \mathrm{mL}$. They were submitted to a dose-response study for MIC determination. From the results, their MIC values ranged from 1.25 to $5 \mathrm{mg} / \mathrm{mL}$ depending on the extract type and the microorganism (Table 3). The extracts, $P g 1^{\mathrm{I}}, P g 1^{\mathrm{M}}, T d 1^{\mathrm{I}}$, and $T d \mathrm{l}^{\mathrm{M}}$ exhibited identical activity profile against enteropathogenic Escherichia coli. The infused $\left(P g 1^{\mathrm{I}}\right)$ and macerated $\left(P g 1^{\mathrm{M}}\right)$ extracts from leaves of $P$. guajava showed inhibition against three bacteria with MIC values of $1.25 \mathrm{mg} / \mathrm{mL}$. Overall, extracts $P g l^{\mathrm{I}}, P g 1^{\mathrm{D}}$ and $T d l^{\mathrm{I}}$ with MIC values of $1.25,2.5$ and $1.25 \mathrm{mg} / \mathrm{mL}$ were selected for the combination studies on enteropathogenic Escherichia coli, the most sensitive bacteria.

\section{Activity of Combined extracts and antibiotic against Enteropathogenic Escherichia coli}

The antibacterial activity of the combination of extracts $\left(T d \mathrm{l}^{\mathrm{I}} / P g \mathrm{l}^{\mathrm{I}}\right.$, and $\left.T d \mathrm{l}^{\mathrm{I}} / P g \mathrm{l}^{\mathrm{D}}\right)$, and extracts with antibiotic $\left(T d \mathrm{l}^{\mathrm{I}} /\right.$ Oxy, $P g 1^{\mathrm{I}} / \mathrm{Oxy}$ and $\left.P g 1^{\mathrm{D}} / \mathrm{Oxy}\right)$ were evaluated against enteropathogenic Escherichia coli (EPEC) in the 96-well plate format.

Overall, the combinations of active extracts exhibited indifference type of interaction with the mean of fractional inhibitory concentrations (FICI) of 1.26 for $T d \mathrm{l}^{\mathrm{L}} / P g \mathrm{l}^{\mathrm{D}}$ and 
Table 2 Medicinal plants species, Plants parts used, modes of preparation and administration to treat rabbit diseases

\begin{tabular}{|c|c|c|c|c|c|c|c|c|c|}
\hline \multirow[t]{2}{*}{ Family } & \multirow{2}{*}{$\begin{array}{l}\text { Plant species } \\
\text { (voucher } \\
\text { number) }\end{array}$} & \multirow[t]{2}{*}{$\begin{array}{l}\text { Common } \\
\text { name }\end{array}$} & \multirow[t]{2}{*}{$\begin{array}{l}\text { Diseases } \\
\text { treated }\end{array}$} & \multirow[t]{2}{*}{ Plant Part } & \multirow[t]{2}{*}{$\begin{array}{l}\text { Method of } \\
\text { preparation }\end{array}$} & \multirow[t]{2}{*}{$\begin{array}{l}\text { Administra- } \\
\text { tion route }\end{array}$} & \multicolumn{3}{|c|}{$\begin{array}{l}\text { Number of recurrences (\% Citation } \\
\text { frequency) }\end{array}$} \\
\hline & & & & & & & $\begin{array}{l}\text { Total } \\
(\mathrm{N}=32)\end{array}$ & $\begin{array}{l}\text { Centre } \\
\text { Region } \\
(\mathrm{N}=5)\end{array}$ & $\begin{array}{l}\text { West Region } \\
(\mathrm{N}=27)\end{array}$ \\
\hline Anonaceae & $\begin{array}{l}\text { Annona } \\
\quad \text { muricata } \\
\text { Linn } \\
\text { (18,681 } \\
\text { SRF/ Cam) }\end{array}$ & Sawasoft & Diarrhoea & Leaves & $\begin{array}{l}\text { Maceration } \\
\text { in water }\end{array}$ & Oral & $4(12.50 \%)$ & $2(40 \%)$ & $2(7.41 \%)$ \\
\hline \multirow[t]{7}{*}{ Asteraceae } & $\begin{array}{l}\text { Bidens } \\
\text { pilosa } \\
\text { Linn. } \\
(41,693 \\
\text { HNC) }\end{array}$ & Bidens & Diarrhoea & $\begin{array}{l}\text { Fresh aerial } \\
\text { part }\end{array}$ & $\begin{array}{l}\text { Maceration } \\
\text { in water }\end{array}$ & Oral & $24(75 \%)$ & $2(40 \%)$ & $22(81.48 \%)$ \\
\hline & $\begin{array}{l}\text { Chromo- } \\
\text { nelaena } \\
\text { odorata } \\
\text { L }(9520 \\
\text { HNC) }\end{array}$ & Chromonella & Diarrhoea & Fresh leaves & $\begin{array}{l}\text { Maceration } \\
\text { in water }\end{array}$ & Oral & $8(25 \%)$ & $1(20 \%)$ & $7(25.93 \%)$ \\
\hline & $\begin{array}{l}\text { Emilia } \\
\text { coccinea } \\
\text { (Sims) } \\
\text { G. Don } \\
(41,003 \\
\text { HNC) }\end{array}$ & Emilia & Diarrhoea & Fresh leaves & $\begin{array}{l}\text { Maceration } \\
\text { in water }\end{array}$ & Oral & $10(31.25 \%)$ & $0(0 \%)$ & $10(37.04 \%)$ \\
\hline & $\begin{array}{l}\text { Emilia prac- } \\
\quad \text { ternissa } \\
\text { Milne-redh } \\
(45,671 \\
\text { HNC) }\end{array}$ & Emilia & Diarrhoea & Fresh leaves & $\begin{array}{l}\text { Maceration } \\
\text { in water }\end{array}$ & Oral & $4(12.50 \%)$ & $1(20 \%)$ & $3(11.11 \%)$ \\
\hline & $\begin{array}{l}\text { Synedrella } \\
\text { nodiflora } \\
\text { Gaertn } \\
(19,308 \text { SRF } \\
\text { Cam) }\end{array}$ & Synedrella & Diarrhoea & Fresh leaves & $\begin{array}{l}\text { Maceration } \\
\text { in water }\end{array}$ & Oral & $2(6.25 \%)$ & $1(20 \%)$ & $1(3.70 \%)$ \\
\hline & $\begin{array}{l}\text { Tithonia } \\
\text { diversifolia } \\
\text { (Hemsl.) } \\
\text { A. Gray } \\
(57,410 \\
\text { HNC) }\end{array}$ & $\begin{array}{l}\text { Fleur jalou- } \\
\text { sie }\end{array}$ & Diarrhoea & Leaves & $\begin{array}{l}\text { Maceration } \\
\text { in water }\end{array}$ & Oral & $2(6.25 \%)$ & $0(0 \%)$ & $2(7.41 \%)$ \\
\hline & $\begin{array}{l}\text { Vernonia } \\
\text { amygda- } \\
\text { lina Del. } \\
\text { (9534 SRF } \\
\text { Cam) }\end{array}$ & Ndole & $\begin{array}{c}\text { Diarrhoea/ } \\
\text { Swelling } \\
\text { stomach }\end{array}$ & Leaves & $\begin{array}{l}\text { Maceration } \\
\text { in water }\end{array}$ & Oral & $6(18.75 \%)$ & $1(20 \%)$ & $5(18.52 \%)$ \\
\hline \multirow[t]{2}{*}{ Caricaceae } & $\begin{array}{l}\text { Carica } \\
\text { papaya } \\
\text { Linn }\end{array}$ & Pawpaw & $\begin{array}{c}\text { Diarrhoea/ } \\
\text { Swelling } \\
\text { stomach }\end{array}$ & Fresh leaves & $\begin{array}{l}\text { Maceration } \\
\text { in water }\end{array}$ & Oral & $4(12.50 \%)$ & $0(0 \%)$ & $4(14.81 \%)$ \\
\hline & $\begin{array}{l}(16,254 \\
\text { SRF/Cam })\end{array}$ & & Diarrhoea & seeds & $\begin{array}{l}\text { Mixed with } \\
\text { feed }\end{array}$ & Oral & 18 & - & \\
\hline $\begin{array}{l}\text { Euphorbi- } \\
\text { aceae }\end{array}$ & $\begin{array}{l}\text { Euphorbia } \\
\text { hirta Linn } \\
(16,218 \\
\text { HNC) }\end{array}$ & Euphorbia & Diarrhoea & $\begin{array}{l}\text { Fresh aerial } \\
\text { part }\end{array}$ & $\begin{array}{l}\text { Maceration } \\
\text { in water }\end{array}$ & Oral & $16(50 \%)$ & $1(20 \%)$ & $15(55.56 \%)$ \\
\hline
\end{tabular}


Table 2 (continued)

\begin{tabular}{|c|c|c|c|c|c|c|c|c|c|}
\hline \multirow[t]{2}{*}{ Family } & \multirow{2}{*}{$\begin{array}{l}\text { Plant species } \\
\text { (voucher } \\
\text { number) }\end{array}$} & \multirow[t]{2}{*}{$\begin{array}{l}\text { Common } \\
\text { name }\end{array}$} & \multirow[t]{2}{*}{$\begin{array}{l}\text { Diseases } \\
\text { treated }\end{array}$} & \multirow[t]{2}{*}{ Plant Part } & \multirow[t]{2}{*}{$\begin{array}{l}\text { Method of } \\
\text { preparation }\end{array}$} & \multirow[t]{2}{*}{$\begin{array}{l}\text { Administra- } \\
\text { tion route }\end{array}$} & \multicolumn{3}{|c|}{$\begin{array}{l}\text { Number of recurrences (\% Citation } \\
\text { frequency) }\end{array}$} \\
\hline & & & & & & & $\begin{array}{l}\text { Total } \\
(\mathrm{N}=32)\end{array}$ & $\begin{array}{l}\text { Centre } \\
\text { Region } \\
(\mathrm{N}=5)\end{array}$ & $\begin{array}{l}\text { West Region } \\
(\mathrm{N}=27)\end{array}$ \\
\hline Fabaceae & $\begin{array}{l}\text { Calliandra } \\
\text { Suramensis } \\
(52,065 \\
\text { HNC) }\end{array}$ & Calliandra & Diarrhoea & Fresh leaves & $\begin{array}{l}\text { Maceration } \\
\text { in water }\end{array}$ & Oral & $1(3.13 \%)$ & $1(20 \%)$ & $0(0 \%)$ \\
\hline Malvaceae & $\begin{array}{l}\text { Gossidium } \\
\text { bar- } \\
\text { badenseL. } \\
\text { (25,771 } \\
\text { SRF/Cam) }\end{array}$ & Cotton & Diarrhoea & Fresh leaves & $\begin{array}{l}\text { Maceration } \\
\text { in water }\end{array}$ & Oral & $5(15.63 \%)$ & $1(20 \%)$ & $4(14.81 \%)$ \\
\hline Meliaceae & $\begin{array}{l}\text { Azadirachta } \\
\text { indica } \\
\text { A.Juss } \\
(4447 \\
\text { SRFK) }\end{array}$ & Neem & Diarrhoea & Fresh leaves & $\begin{array}{l}\text { Maceration } \\
\text { in water }\end{array}$ & Oral & $3(9.37 \%)$ & $1(20 \%)$ & $2(7.41 \%)$ \\
\hline Moringaceae & $\begin{array}{l}\text { Moringa } \\
\text { Oleifera } \\
\text { Lam (4917 } \\
\text { HNC) }\end{array}$ & Moringa & Diarrhoea & Fresh leaves & $\begin{array}{l}\text { Maceration } \\
\text { in water }\end{array}$ & Oral & $5(15.63 \%)$ & $1(20 \%)$ & $4(14.81 \%)$ \\
\hline \multirow[t]{2}{*}{ Musaceae } & \multirow{2}{*}{$\begin{array}{l}\text { Psidium } \\
\text { guajava } \\
\text { Linn }(2884 \\
\text { SRFK) }\end{array}$} & \multirow[t]{2}{*}{ Guava } & Diarrhoea & Fresh leaves & $\begin{array}{l}\text { Maceration } \\
\text { in water }\end{array}$ & Oral & $17(53.13 \%)$ & $3(60 \%)$ & $14(51.85 \%)$ \\
\hline & & & Diarrhoea & Seeds & $\begin{array}{l}\text { Mixed with } \\
\text { feed }\end{array}$ & Oral & 6 & - & - \\
\hline \multirow{2}{*}{\multicolumn{2}{|c|}{ Other natural substances }} & Charcoal & Diarrhoea & Powder & $\begin{array}{l}\text { Mixed with } \\
\text { feed }\end{array}$ & Oral & 18 & - & - \\
\hline & & $\begin{array}{l}\text { Palm oil- } \\
\text { kerosene }\end{array}$ & rashes & - & Mixed & $\begin{array}{l}\text { Applied } \\
\text { topically }\end{array}$ & 18 & - & - \\
\hline
\end{tabular}

Table 3 Minimal inhibitory concentration $(\mathrm{mg} / \mathrm{mL})$ of selected extracts against the three bacterial strains

\begin{tabular}{llll}
\hline Extracts & E. coli EPEC & S. enterica & C. perfringens \\
\hline$T d \mathrm{l}^{\mathrm{M}}$ & $1.25 \pm 0.0$ & $2.5 \pm 0.0$ & $2.5 \pm 0.0$ \\
$T d \mathrm{l}^{\mathrm{I}}$ & $1.25 \pm 0.0$ & $2.5 \pm 0.0$ & $2.5 \pm 0.0$ \\
$T d \mathrm{l}^{\mathrm{D}}$ & $2.5 \pm 0.0$ & $2.5 \pm 0.0$ & $5.0 \pm 0.0$ \\
$P g \mathrm{1}^{\mathrm{M}}$ & $1.25 \pm 0.0$ & $1.25 \pm 0.0$ & $1.25 \pm 0.0$ \\
$P g \mathrm{l}^{\mathrm{I}}$ & $1.25 \pm 0.0$ & $1.25 \pm 0.0$ & $1.25 \pm 0.0$ \\
$P g \mathrm{l}^{\mathrm{D}}$ & $2.5 \pm 0.0$ & $2.5 \pm 0.0$ & $1.25 \pm 0.0$ \\
Oxytetracy- & $0.1 \times 10^{-6} \pm 0.0$ & $7.9 \times 10^{-6} \pm 0.0$ & $0.2 \times 10^{-6} \pm 0.0$ \\
cline 20\% & & & \\
\hline
\end{tabular}

EPEC: Enteropathogenic Escherichia coli; $T d \mathrm{l}^{\mathrm{M}}$ : macerated leaf of Tithonia diversifolia; $T d \mathrm{l}^{\mathrm{I}}$ : infused leaf of $T$. diversifolia; $T d \mathrm{l}^{\mathrm{D}}$ : decocted leaf of $T$. diversifolia, $\mathrm{Pgl}^{\mathrm{M}}$ : macerated leaf of $P$. guajava; $P g 1^{\mathrm{I}}$ : infused leaf of $P$. guajava, $P g \mathrm{l}^{\mathrm{D}}$ : decocted leaf of $P$. guajava

1.65 for $T d 1^{\mathrm{I}} / P g \mathrm{l}^{\mathrm{I}}$ (Table 4). However, the combination of extracts $T d \mathrm{l}^{\mathrm{I}}$ and $P g \mathrm{l}^{\mathrm{D}}$ exhibited synergistic interaction with FICI of $0.312,0.281$, and 0.265 . Moreover, the analysis of data revealed a 16 to $64\left(T d \mathrm{l}^{\mathrm{I}}\right)$ and 4 times $\left(P g \mathrm{l}^{\mathrm{D}}\right)$ reduction of the MIC values of both extracts when compared
Table 4 Effects of combined extracts and extracts with Oxytetracycline on enteropathogenic Escherichia coli

\begin{tabular}{llll}
\hline Combinations & FICs & FICI & Interaction \\
\hline$T d 1^{\mathrm{I} / P g 1^{\mathrm{I}}}$ & $1.154 / 0.498$ & 1.652 & Indifference \\
$T d 1^{\mathrm{I} / P g 1^{\mathrm{D}}}$ & $0.998 / 0.268$ & 1.266 & Indifference \\
$T d \mathrm{l}^{\mathrm{I}} / \mathrm{Oxy}$ & $0.497 / 1.125$ & 1.622 & Indifference \\
$P g 1^{\mathrm{D}} / \mathrm{Oxy}$ & $0.269 / 0.498$ & 0.767 & Additivity \\
$P g 1^{\mathrm{I}} / \mathrm{Oxy}$ & $0.534 / 0.447$ & 0.981 & Additivity \\
\hline
\end{tabular}

$T d l^{I}$ : infused leaf of $T$. diversifolia; $P g 1^{\mathrm{I}}$ : the infused leaf of $P . g u a-$ java; $P g 1^{\mathrm{D}}$ : the decocted leaf of $P$. guajava; Oxy: Oxytetracycline; FIC: fractional inhibitory concentration; FICI: fractional inhibitory concentration index

to each extract tested alone (supplementary material 1). These results demonstrate the efficacy of the combination of extracts from $T$. diversifolia and $P$. guajava compared to their extracts alone.

The combinations of selected extracts with Oxytetracycline $20 \%$ exhibited additivity for combinations $P g \mathrm{I}^{\mathrm{D}} / \mathrm{Oxy}$ and $P g 1^{\mathrm{D}} / \mathrm{Oxy}$ and indifference for $T d \mathrm{l}^{\mathrm{I}} / \mathrm{Oxy}$ with the calculated mean of fractional inhibitory concentrations ranging 
Table 5 Phytochemical composition of extracts of $T$. diversifolia $\left(T d \mathrm{l}^{\mathrm{M}}, T d \mathrm{l}^{\mathrm{I}}, T d \mathrm{l}^{\mathrm{D}}\right)$ and $P$. guajava $\left(P g 1^{\mathrm{M}}, P g 1^{\mathrm{I}}\right.$, $P g 1^{\mathrm{D}}$ )

\begin{tabular}{llclccc}
\hline Phytochemicals & $T d \mathrm{l}^{\mathrm{M}}$ & $T d \mathrm{l}^{\mathrm{I}}$ & $T d \mathrm{l}^{\mathrm{D}}$ & $P g \mathrm{l}^{\mathrm{M}}$ & $P g \mathrm{l}^{\mathrm{I}}$ & $P g \mathrm{l}^{\mathrm{D}}$ \\
\hline Flavonoids & + & + & + & + & + & + \\
Glycosides & + & + & + & + & + & + \\
Phenols & + & + & + & + & + & + \\
Anthraquinones & + & + & + & + & + & + \\
Tannins & + & + & + & + & + & + \\
Terpenoids & + & + & + & + & + & + \\
Saponins & + & + & + & + & + & + \\
Steroids & - & - & - & - & - & - \\
\hline
\end{tabular}

+ : present; -: absent; $T d l^{M}$ : the macerated leaf of $T$. diversifolia; $T d l^{I}$ : the infused leaf of $T$. diversifolia; $T d l^{D}$ : the decocted leaf of $T$. diversifolia; $P g 1^{\mathrm{M}}$ : the macerated leaf of $P$. guajava; $P g 1^{\mathrm{I}}$ : the infused leaf of $P$. guajava; $P g 1^{\mathrm{D}}$ : the decocted leaf of $P$. guajava from 0.767 to 1.622 . Interestingly, the combination of extract $P g 1^{\mathrm{D}}$ and Oxy exhibited synergistic interaction with FICI of 0.5 (supplementary material 2 ). The analysis of data revealed that a MIC in combination was fivefold lower than their MIC tested alone, and the extract was found to improve the activity of oxytetracycline. Overall, these results show the efficacy of the combined extracts from $P$. guajava with oxytetracycline. In both cases, no case of antagonism was observed.

\section{Phytochemical composition of extracts}

The selected extracts were submitted to qualitative phytochemical analysis and the results are summarized in the Table 5.

The phytochemical screening presented in Table 5 shows that the families of secondary metabolites involved in the biological activities are well distributed in the different plant extracts. Indeed, in all the extracts, flavonoids, glycosides, phenols, tannins, terpenoids, saponins, and anthraquinones were present while steroids were absent.

\section{Discussion}

Rabbit meat is a great functional food and offers excellent nutritive and dietetic properties. In addition, rabbit farming has the great potential of supplying high-quality meat across the globe. However, the high mortality rate due to bacterial enteritis is a constant challenge for rabbit farmers. In order to manage rabbit diseases, various conventional drugs and medicinal plants are widely used locally by breeders (Lans and Turner 2011; González et al. 2011; Dzoyem et al. 2020). Given the limited information regarding the management of bacterial enteritis by Cameroonian breeders, using the ethnopharmacological survey approach, we investigated the use of medicinal plants by local farmers in five localities in Cameroon. The medicinal plants were collected, identified, and submitted to antimicrobial activity against causative agents of enteritis in rabbits.

The ethnopharmacological survey revealed that rabbit farming in localities investigated is dominated by male representing about $85 \%$ of informants with age ranging from 20 to 49 years old. This dominance of men could be associate with cultural reasons (Lateef et al. 2020). The majority of informants $(68.09 \%)$ reported using local medicinal plants to treat rabbits' diseases. Indeed, fifteen medicinal plants belonging to nine families were identified, with plants from the Asteraceae family being the most represented. The consistent use of Asteraceae in all the localities investigated could be associated with their bioavailability. Besides, this family counts hundreds of medicinal plants distributed across the Cameroon territory, and their use for traditional medicine and food purposes is well-known by local populations (Dzoyem et al. 2020). The plant $P$. guajava (51.85-53.13\%) was reported to be one of the most common trees frequently used in the management of rabbit diarrhoea in both regions of Cameroon. This medicinal plant is very well-known for its usefulness against gastroenteritis, dysentery, stomach pain and indigestion in human and animals (Hirudkar et al. 2020; Lateef et al. 2020). Most of the informants $(86.66 \%)$ reported using leaves macerated in water to cure animals by oral administration. This proclivity to use leaves could be due to several reasons such as the eco-friendliness, facility and simplicity of the plants' harvest procedure, and their antibacterial secondary metabolites content (Hirudkar et al. 2020). In addition, it is recognized that small ruminants such as rabbits easily consume plants leaves as food. Maceration of leaves to prepare medicines was reported as the most common mode of treatment of animal disease in ethnoveterinary medicine (Ritter et al. 2012; Romha et al. 2015; Jaradat et al. 2016; Dzoyem et al. 2020).

Out of the 45 extracts prepared from the 15 medicinal plants collected, only six extracts, including three from leaves of $T$. diversifolia $\left(T d \mathrm{l}^{\mathrm{M}}, T d \mathrm{l}^{\mathrm{I}}, T d \mathrm{l}^{\mathrm{D}}\right)$ and three from leaves of $P$. guajava $\left(P g 1^{\mathrm{M}}, P g 1^{\mathrm{I}}, P g 1^{\mathrm{D}}\right)$, were active against 
tested bacteria with MIC values ranged from 1.25 to $5 \mathrm{mg} /$ $\mathrm{mL}$ depending on the extract type and the microorganism. Previous studies showed that extracts from leaves of these two plants possess antibacterial activity (Gonçalves et al. 2008; Oso and Ogunnusi 2017; Oncho et al. 2021). These results are in support of our survey data, reporting the use of $P$. guajava in all the localities investigated. These results might suggest that extracts from these plants contain metabolites with activity against bacterial pathogens. Indeed, our phytochemical screening reveals the presence of flavonoids, glycosides, phenols, tannins, terpenoids, saponins, and anthraquinones. These secondary metabolites are well-known for their antimicrobial activity (Altemimi et al. 2017; Ajao and Moteetee 2017; Omokhua et al. 2018; Oncho et al. 2021). The antibacterial activity of the combination of extracts from both plants showed that combining extracts $T d \mathrm{l}^{\mathrm{I}}$ and $P g \mathrm{l}^{\mathrm{D}}$ exhibited synergistic interaction with a 16-64-fold $\left(T d l^{\mathrm{I}}\right)$ and 4-times $\left(P g \mathrm{l}^{\mathrm{D}}\right)$ reduction of MIC values of both extracts when compared to each extract tested alone. The combination of extracts with Oxytetracycline 20\% exhibited additives and indifference type of interaction with the fivefold decrease in the MIC of oxytetracycline, revealing the potential of extract to improve the antibiotic activity. Morais-Braga et al. (2016) previously reported an improved antibacterial potency of the association between aqueous extract of $P$. guajava and various antibiotics, including tetracycline, Ciprofloxacin, gentamicin and amikacin. These findings elucidated a vital interest of the synergistic interactions obtained with the combination of extracts together and with an antibiotic that increases therapeutic efficiency, reduce the dose administrate, and decrease of undesirable effects, as compared with the efficacy of each agent alone.

\section{Conclusion}

Rabbit farming is challenged by bacterial enteritis. Our investigation into five localities in Cameroon led to the identification of fifteen medicinal plants currently used to treat diarrhoea in rabbits. The investigation of the antibacterial potential of the 45 extracts obtained identified six active extracts from $T$. diversifolia and $P$. guajava. The combination of both plants with oxytetracycline revealed positive interaction with enhanced activity. The demonstration of the activity of both $T$. diversifolia and $P$. guajava against causative agent of bacterial enteritis supports the traditional use of these plants in the treatment of rabbit diarrhoea. Data collected in the present study represent a database on the medicinal plants used in rabbit farming in some localities of Cameroon. Other antibacterial guided separations of active extracts from the present study are underway to identify potential active ingredients for a proper formulation and standardisation of a potent recipe against rabbit's bacterial enteritis.

Supplementary Information The online version contains supplementary material available at https://doi.org/10.1007/s13596-021-00615-1.

Acknowledgements The authors are grateful to all informants, who participated in this survey, by providing information on medicinal plants used in the treatment of rabbit's diseases; BEI-Resources and IRAD Wakwa-Ngaoundéré Cameroon, for graciously offering the strain of Clostridium perfringens WAL-14572 HM-310 and isolates of Enteropathogenic Escherichia coli and Salmonella enterica. The National Herbarium of Cameroon, for identification of plant species.

Authors' contributions MTC participated in all field data collection, laboratory experiment and wrote the manuscript. MSM analysed data and wrote the manuscript. LVY participated in laboratory studies and reviewed the manuscript. EZM participated in laboratory studies and reviewed the manuscript. RMKT participated, supervised all experiments, and drafted the manuscript. KAE and FFB supervised the study and revised manuscript. All the authors have read and approved the final manuscript.

Funding Open Access funding provided thanks to the CRUE-CSIC agreement with Springer Nature. No funding supported this study.

\section{Declarations}

Ethical statement This article does not contain any studies involving animals performed by any of the authors. This article does not contain any studies involving human participants performed by any of the authors.

Conflict of interest Mireille Tuedom Chouegouong has no conflict of interest. Michele Stella Majoumouo has no conflict of interest. Elisabeth Zeuko'o Menkem has no conflict of interest. Lorette Victorine Yimgang has no conflict of interest. Rufin Marie Kouipou Toghueo has no conflict of interest. Kingsley Agbor Etchu has no conflict of interest. Fabrice Fekam Boyom has no conflict of interest.

Open Access This article is licensed under a Creative Commons Attribution 4.0 International License, which permits use, sharing, adaptation, distribution and reproduction in any medium or format, as long as you give appropriate credit to the original author(s) and the source, provide a link to the Creative Commons licence, and indicate if changes were made. The images or other third party material in this article are included in the article's Creative Commons licence, unless indicated otherwise in a credit line to the material. If material is not included in the article's Creative Commons licence and your intended use is not permitted by statutory regulation or exceeds the permitted use, you will need to obtain permission directly from the copyright holder. To view a copy of this licence, visit http://creativecommons.org/licenses/by/4.0/.

\section{References}

Ajao AA, Moteetee AN (2017) Tithonia diversifolia (Hemsl) A. Gray. (Asteraceae: Heliantheae), an invasive plant of significant ethnopharmacological importance: a review. S Afr J Bot 113:396-403. https://doi.org/10.1016/j.sajb.2017.09.017 
Altemimi A, Lakhssassi N, Baharlouei A et al (2017) Phytochemicals: extraction, isolation, and identification of bioactive compounds from plant extracts. Plants 6:42. https://doi.org/10.3390/plant s6040042

Dalle Zotte A, Szendrő Z (2011) The role of rabbit meat as functional food. Meat Sci 88:319-331. https://doi.org/10.1016/j.meatsci. 2011.02.017

DeCubellis J, Graham J (2013) Gastrointestinal disease in guinea pigs and rabbits. Vet Clin N Am Exotic Anim Pract 16:421-435. https://doi.org/10.1016/j.cvex.2013.01.002

Dzoyem JP, Tchuenteu RT, Mbarawa K et al (2020) Ethnoveterinary medicine and medicinal plants used in the treatment of livestock diseases in Cameroon. In: McGaw LJ, Abdalla MA (eds) Ethnoveterinary medicine. Springer, Cham, pp 175-209

El-Ashram S, Aboelhadid SM, Abdel-Kafy E-SM, et al (2020) Erratum: Saeed, E.-A.; Shawky, M.A.; El-Sayed, M.A.-K.; Shymaa, A.H.; Lilian, N.M.; Eman, M.F.; Asmaa, A.K. Investigation of Pre- and Post-Weaning Mortalities in Rabbits Bred in Egypt, with Reference to Parasitic and Bacterial Causes. Animals 2020, 10, 537. Animals 10:650. https://doi.org/10.3390/ani10040650

FAOSTAT Food and Agriculture Data. http://www.fao.org/faostat/en/\#data

Gómez E (2006) Producción industrial De Gazapos: Algunos Puntos Críticos. 12

Gonçalves FA, Andrade Neto M, Bezerra JNS et al (2008) Antibacterial activity of GUAVA, Psidium guajava Linnaeus, leaf extracts on diarrhea-causing enteric bacteria isolated from Seabob shrimp, Xiphopenaeus kroyeri (Heller). Rev Inst Med Trop S Paulo 50:1115. https://doi.org/10.1590/S0036-46652008000100003

González JA, García-Barriuso M, Amich F (2011) Ethnoveterinary medicine in the Arribes del Duero, western Spain. Vet Res Commun 35:283-310. https://doi.org/10.1007/s11259-011-9473-y

Harborne JB (1998) Phytochemical methods: a guide to modern techniques of plant analysis, 3rd edn. Chapman \& Hall, London

Hernández P, Zotte AD (2010) Influence of diet on rabbit meat quality. In: de Blas C, Wiseman J, Allain D et al (eds) Nutrition of the rabbit, 2nd edn. CABI, Wallingford, pp 163-178

Hirudkar JR, Parmar KM, Prasad RS et al (2020) The antidiarrhoeal evaluation of Psidium guajava L. against enteropathogenic Escherichia coli induced infectious diarrhoea. J Ethnopharmacol 251:112561. https://doi.org/10.1016/j.jep.2020.112561

Jaradat NA, Ayesh OI, Anderson C (2016) Ethnopharmacological survey about medicinal plants utilized by herbalists and traditional practitioner healers for treatments of diarrhea in the West Bank/ Palestine. J Ethnopharmacol 182:57-66. https://doi.org/10.1016/j. jep.2016.02.013

Kupczyński R, Piasecki T, Bednarski M et al (2016) Application of herbs and propolis in rabbits with chronic diarrhea. Turk J Vet Anim Sci 8:344-351

Kupczyński R, Szumny A, Bednarski M et al (2019) Application of Pontentilla anserine, Polygonum aviculare and Rumex crispus mixture extracts in a rabbit model with experimentally induced E. coli infection. Animals 9:774. https://doi.org/10.3390/ani91 00774

Kylie J, McEwen SA, Boerlin P et al (2017) Prevalence of antimicrobial resistance in fecal Escherichia coli and Salmonella enterica in Canadian commercial meat, companion, laboratory, and shelter rabbits (Oryctolagus cuniculus) and its association with routine antimicrobial use in commercial meat rabbits. Prev Vet Med 147:53-57. https://doi.org/10.1016/j.prevetmed.2017.09.004

Lans C, Turner N (2011) Organic parasite control for poultry and rabbits in British Columbia. Can J Ethnobiol Ethnomed 7:21. https:// doi.org/10.1186/1746-4269-7-21

Lateef AA, Smart O, Toba SA, Olatunde PA (2020) Medicinal plants used in ethnoveterinary practices in the Federal Capital Territory, North-Central Nigeria. J Med Plants Res 14:377-388. https://doi. org/10.5897/JMPR2020.6975
Martin GJ (1995) Ethnobotany. Springer, US, Boston, MA

McNitt JI, Lukefahr SD, Cheeke PR, Patton NM (2013) Rabbit diseases and health problems. In: McNitt JI, Lukefahr SD, Cheeke PR, Patton NM (eds) Rabbit production, 9th edn. CABI, Wallingford, pp 112-143

Meineri G, Cornale P, Tassone S, Peiretti PG (2010) Effects of Chia (Salvia hispanica L.) seed supplementation on rabbit meat quality, oxidative stability and sensory traits. Ital J Anim Sci 9:10. https:// doi.org/10.4081/ijas.2010.e10

Morais-Braga MFB, Carneiro JNP, Machado AJT et al (2016) Psidium guajava L., from ethnobiology to scientific evaluation: Elucidating bioactivity against pathogenic microorganisms. J Ethnopharmacol 194:1140-1152. https://doi.org/10.1016/j.jep.2016.11.017

Moustapha M, Deirmendjian L, Sebag D, et al (2021) Partitioning carbon sources in a tropical watershed (Nyong River, Cameroon) between wetlands and terrestrial ecosystems-Do CO\&lt;sub\&gt;2\&lt;/sub\&gt; emissions from tropical rivers offset the terrestrial carbon sink? Biogeochemistry: Greenhouse Gases

Nematchoua MK, Tchinda R, Ricciardi P, Djongyang N (2014) A field study on thermal comfort in naturally-ventilated buildings located in the equatorial climatic region of Cameroon. Renew Sustain Energy Rev 39:381-393. https://doi.org/10.1016/j.rser.2014.07. 010

Oglesbee BL, Lord B (2020) Gastrointestinal diseases of rabbits. In: Ferrets, Rabbits, and Rodents. Elsevier, pp 174-187

Omokhua AG, Abdalla MA, Van Staden J, McGaw LJ (2018) A comprehensive study of the potential phytomedicinal use and toxicity of invasive Tithonia species in South Africa. BMC Complement Altern Med 18:272. https://doi.org/10.1186/s12906-018-2336-0

Oncho DA, Ejigu MC, Urgessa OE (2021) Phytochemical constituent and antimicrobial properties of guava extracts of east Hararghe of Oromia. Ethiopia Clin Phytosci 7:37. https://doi.org/10.1186/ s40816-021-00268-2

Oso B, Ogunnusi T (2017) Antibacterial Activity of METHANOLIC EXTRACTS of Euphorbia heterophylla and Tithonia diversifolia against some microorganisms. EJMP 20:1-8. https://doi.org/10. 9734/EJMP/2017/28568

Pasupathi K, Muthusamy P, Gopi H et al (2014) Survivability in New Zealand white breed of rabbits under farming condition in Tamilnadu. Int J Sci Environ Technol 3:1772-1777

Powell A (2021) Africa's New White Meat: Rabbit. 3

Ritter RA, Monteiro MVB, Monteiro FOB et al (2012) Ethnoveterinary knowledge and practices at Colares island, Pará state, eastern Amazon, Brazil. J Ethnopharmacol 144:346-352. https://doi.org/ 10.1016/j.jep.2012.09.018

Romha G, Dejene TA, Telila LB, Bekele DF (2015) Ethnoveterinary medicinal plants: Preparation and application methods by traditional healers in selected districts of southern Ethiopia. Vet World 8:674-684. https://doi.org/10.14202/vetworld.2015.674-684

Rosell JM, de la Fuente LF (2009) Culling and mortality in breeding rabbits. Prev Vet Med 88:120-127. https://doi.org/10.1016/j.preve tmed.2008.08.003

Szabóová R, Lauková A, Chrastinová L' et al (2012) Benefficial effect of plant extracts in rabbit husbandry. Acta Vet Brno 81:245-250. https://doi.org/10.2754/avb201281030245

Tchetgna MS (2012) Guide culturel et touristique de la province de l'ouest du Cameroun

van Vuuren S, Viljoen A (2011) Plant-based antimicrobial studiesmethods and approaches to study the interaction between natural products. Planta Med 77:1168-1182. https://doi.org/10.1055/s0030-1250736

Publisher's Note Springer Nature remains neutral with regard to jurisdictional claims in published maps and institutional affiliations. 